\title{
DIFERENSIAL LEUKOSIT IKAN GURAMI (Osphronemus gouramy Lac.) DENGAN PERBEDAAN LEVEL SUPLEMENTASI Spirulina platensis DALAM PAKAN
}

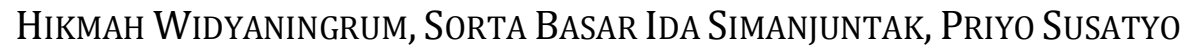

Fakultas Biologi, Universitas Jenderal Soedirman, Jalan dr. Suparno 63 Purwokerto 53122

\section{A B S T R A C T}

The aim of this research was to know the effect of supplemented Spirulina platensis in diet on leukocytes differential of gourami (Osphronemous gouramy Lac.) and to obtain the best dose. This research was carried out experimentally using a completely randomized design (RAL), which consists of 4 treatments and 3 repetitions. The fish fed with diets which contain different levels of $(0,2.4$, and $6 \mathrm{~g} / \mathrm{kg})$ Spirulina platensis were investigated. Sampling was done 4 times at intervals of 2 weeks of the feeding experiment, leukocyte differential (monocyte, lymphocyte, neutrophil, eosinophyl) of blood taken from fish were determined. The results showed that the highest percentage of lymphocytes was found in level of supplementation of $4 \mathrm{~g} / \mathrm{kg}$ of diets, whereas the highest percentage of monocytes, neutrophils and eosinophils were found at the level suplemetation $2 \mathrm{~g} / \mathrm{kg}$ of diets. Level supplementation of S. platensis $4 \mathrm{~g} / \mathrm{kg}$ of diets is an efficient and effective level in stimulating immune system cells of gourami, particularly lymphocytes cell.

KEY WORDS: Gourami (Osphronemus gouramy), immunostimulant, Spirulina platensis, differential leukocyte

Penulis korespondensi: HIKMAH WIDYANINGRUM | email: hikmah.widyaningrum@gmail.com

\section{PENDAHULUAN}

Budidaya ikan gurami merupakan usaha sektor perikanan yang tidak pernah sepi peminat (Bachtiar, 2010). Rukmana (2005) menyatakan bahwa ikan gurami cukup digemari masyarakat karena rasanya yang gurih dan lezat, mudah dicerna dan bergizi tinggi. Di samping itu, harga ikan gurami di pasaran cukup tinggi dan permintaan akan ikan ini masih belum terpenuhi.

Menurut Bachtiar (2010), gurami merupakan jenis ikan yang pertumbuhannya lambat dibandingkan dengan jenis ikan air tawar lainnya. Sementara organisme patogen selalu ada dalam media hidup ikan. Oleh karena itu masalah penyakit infeksi sewaktu-waktu dapat timbul dalam kegiatan perikanan budidaya dan bahkan pada ikan-ikan di perairan umum.

Sahan et al. (2015), menyatakan bahwa alternatif penanggulangan penyakit adalah memberikan pakan bernutrisi yang sekaligus memperkuat kekebalan atau pertahanan tubuh ikan itu sendiri. Menurut Utomo et al. (2012), Spirulina platensis dapat dijadikan sebagai suplemen pada pakan, sehingga pakan tidak hanya berperan dalam pertumbuhan tapi juga sebagai imunostimulan karena dapat meningkatkan daya tahan tubuh ikan.

Abdel-Tawwab \& Ahmad (2009) melaporkan bahwa ikan nila diberi suplemen $S$. platensis 5-10 g/kg pakan memiliki daya tahan tubuh yang baik ketika diuji tantang dengan Aeromonas hydrophyla. Sahan et al. (2015) membuktikan bahwa pemberian $S$. platensis $5 \mathrm{~g} / \mathrm{kg}$ pakan pada ikan nila (Oreochromis niloticus) dapat meningkatkan aktivitas limfosit dan eosinofil, sedangkan pemberian S. platensis 7,5 g/kg pakan dapat meningkatkan jumlah sel darah merah dan sel darah putih ikan
Pengaruh $S$. platensis dalam meningkatkan sistem imun ikan berkaitan dengan level yang diberikan. Sementara itu harga S. platensis masih tergolong mahal, seperti yang dinyatakan oleh Nur (2014), bahwa untuk Spirulina platensis berkisar Rp 200.000$350.000 / \mathrm{kg}$ untuk produk impor. Mengingat hal tersebut maka perlu diadakan penelitian lebih lanjut tentang pengaruh perbedaan level suplementasi $S$. platensis terhadap respon imun ikan gurami serta level suplementasi yang paling efektif dan optimum dengan mengamati diferensial leukosit sebagai parameternya.

Gambaran sel darah merupakan aspek pendukung dalam menentukan status kesehatan ikan. Darah merupakan salah satu komponen pertahanan dari serangan penyakit yang masuk ke dalam tubuh ikan (Purwanto, 2006). Pemeriksaan darah dilakukan untuk melihat pola peningkatan respon imun dengan menghitung total leukosit dan diferensial leukosit dalam darah (Septiarini et al., 2012). Pengamatan diferensial leukosit dalam penelitian ini meliputi pengamatan neutrofil, monosit, eosinofil dan limfosit.

Tujuan penelitian ini adalah untuk mengetahui diferensial leukosit ikan gurami yang diberi suplementasi $S$. platensis dengan level yang berbeda serta mengetahui level suplementasi $S$. platensis yang terbaik terhadap diferensial leukosit ikan gurami.

Hasil penelitian ini diharapkan dapat memberikan informasi ilmiah tentang pengaruh perbedaan level suplementasi $S$. platensis terhadap diferensial leukosit ikan gurami, serta mengetahui level pemberian $S$. platensis yang paling optimum terhadap diferensial leukosit ikan gurami, sehingga dapat dijadikan pedoman untuk strategi pemberian suplemen berupa S. platensis dalam upaya meningkatkan hasil budidaya ikan gurami. 


\section{METODE}

Alat-alat yang digunakan dalam penelitian ini yaitu kolam, sendok, baskom plastik diameter $50 \mathrm{~cm}$, mikroskop, timbangan digital dengan ketelitian 0,01 g, nampan, gelas ukur, object glass, cover glass, beaker glass, handcounter, spuit injeksi, container, selang air, seser, pipet tetes, kamera dan alat tulis. Bahan-bahan yang digunakan dalam penelitian ini yaitu ikan gurami (Osphronemus gouramy), pelet $\mathrm{F}_{1000}$, air, $S$. platensis, akuades, minyak emersi, larutan giemsa 7\%, methanol PA, aluminium foil dan tissue.

Penelitian ini dilaksanakan di Stasiun Percobaan Program Studi D3 Pengelolaan Sumber Daya Perikanan dan Kelautan serta Laboratorium Fisiologi Hewan Fakultas Biologi Universitas Jenderal Soedirman dari bulan FebruariMei 2016. Penelitian ini dilakukan secara eksperimental dengan menggunakan Rancangan Acak Kelompok (RAL) yang terdiri dari 4 perlakuan dan 3 kali ulangan. Perlakuan yang dilakukan selama 8 minggu meliputi:

P1 = diberi pakan pelet komersial;

$\mathrm{P} 2$ = diberi pakan bersuplemen $S$. platensis $2 \mathrm{~g} / \mathrm{kg}$ pakan;

P3 = diberi pakan bersuplemen $S$. platensis $4 \mathrm{~g} / \mathrm{kg}$ pakan;

$\mathrm{P} 4$ = diberi pakan bersuplemen $S$. platensis $6 \mathrm{~g} / \mathrm{kg}$ pakan

Kolam yang digunakan dalam penelitian ini berjumlah 12 buah dengan ukuran 100x100x40 $\mathrm{cm}^{3}$. Sebelum digunakan semua kolam terlebih dahulu dibersihkan. Kolam tersebut selanjutnya diisi air sampai ketinggian $25 \mathrm{~cm}$.

Ikan gurami berumur 5 bulan sebanyak 84 ekor dengan berat 20,43 $\pm 4,116981 \mathrm{~g}$ dan panjang 12,03 $\pm 1,177165 \mathrm{~cm}$. Ikan gurami tersebut dimasukkan ke dalam kolam dengan padat penebaran 7 ekor/250 L. Aklimasi dilakukan selama satu minggu. Pemberian pakan sesuai perlakuan sebanyak dua kali sehari pukul 08.00 dan 16.00 WIB.

Sebanyak $4 \mathrm{~kg}$ pelet disiapkan, dengan $1 \mathrm{~kg}$ pelet sebagai kontrol, sedangkan $3 \mathrm{~kg}$ lainnya dibagi menjadi 3 bagian. $S$. platensis ditimbang sesuai dengan levelnya, yaitu $2 \mathrm{~g}, 4 \mathrm{~g}$ dan 6 g. Masing-masing level dicampurkan dengan akuades sebanyak $100 \mathrm{ml}$, diaduk sampai homogen. Setelah homogen ditambahkan ke dalam pelet yang telah dibagi menjadi 3 bagian, yaitu: campuran akuades $+2 \mathrm{~g}$ S. platensis disuplementasikan kedalam $1 \mathrm{~kg}$ pelet pertama; campuran akuades $+4 \mathrm{~g}$ S. platensis disuplementasikan kedalam $1 \mathrm{~kg}$ pelet kedua; campuran akuades $+6 \mathrm{~g} S$. platensis disuplementasikan kedalam $1 \mathrm{~kg}$ pelet ketiga. Masingmasing pelet kemudian dijemur sampai kering. Setelah kering pelet dimasukkan kedalam container kaca dan ditutup rapat. Pakan siap diujikan pada ikan gurami.

Pemeliharaan ikan dilakukan selama 8 minggu. Pemberian pakan disesuaikan dengan perlakuan yang diujikan yaitu P1: ikan diberi pakan pelet komersial; P2: ikan diberi pakan suplementasi $S$. platensis dengan level 2 g/kg pakan; P3: ikan diberi pakan suplementasi $S$. platensis dengan level $4 \mathrm{~g} / \mathrm{kg}$ pakan dan P4: ikan diberi pakan suplementasi $S$. platensis dengan level $6 \mathrm{~g} / \mathrm{kg}$ pakan. Ikan diberi pakan dengan frekuensi dua kali sehari yaitu pada pagi hari pukul 08.00 dan sore hari pukul 16.00.

Pengambilan sampel dilakukan setiap dua minggu sekali selama 8 minggu. Sebanyak 2 ekor ikan diambil dari masingmasing kolam. Pengambilan darah dilakukan di bagian jantung menggunakan spuit injeksi. Darah langsung diteteskan pada object glass dan dibuat preparat apus.

Darah diteteskan pada objek glass dan diapus dengan kaca pengapus. Ulasan darah yang sudah kering difiksasi dengan methanol $70 \%$ selama 5 menit kemudian dikeringkan, selanjutnya diwarnai dengan giemsa 7\% selama 20 menit dan dikeringanginkan. Setelah itu dicuci dengan menggunakan air kran yang mengalir dan dibiarkan kering di udara terbuka.
Mengacu pada Handari (1983) perbesaran mikroskop 400x dilakukan untuk mengamati hasil ulasan darah untuk melihat limfosit, monosit, neutrofil, dan eosinofil (Gambar 1-4). Svobodova \& Vykusova (1991) menyatakan bahwa penghitungan leukosit dilakukan hingga diperoleh $100 \mathrm{sel}$ leukosit kemudian persentase jenis-jenis leukosit dapat dihitung dengan rumus sebagai berikut:

$$
\text { Jumlah Leukosit Total }(\%)=\frac{\text { komponen sel leukosit }}{100} \times 100 \%
$$

Data persentase neutrofil, eosinofil, limfosit dan monosit dianalisis dengan sidik ragam (ANOVA) dengan tingkat kesalahan 5\% untuk mengetahui pengaruh yang dicobakan. Apabila hasil yang diperoleh berbeda nyata maka dilanjutkan dengan uji BNT.

\section{HASIL DAN PEMBAHASAN}

Berdasarkan uji ANOVA yang dilakukan menunjukkan bahwa pemberian $S$. platensis dengan level suplementasi $2 \mathrm{~g} / \mathrm{kg}$ pakan, $4 \mathrm{~g} / \mathrm{kg}$ pakan, dan $6 \mathrm{~g} / \mathrm{kg}$ pakan memberikan pengaruh yang sangat nyata $(\mathrm{P}<$ 0,01 ) terhadap persentase limfosit ikan gurami. Persentase limfosit tertinggi didapatkan pada level 4 $\mathrm{g} / \mathrm{kg}$ pakan dan $6 \mathrm{~g} / \mathrm{kg}$ pakan (Gambar 5). Sementara itu berdasarkan uji BNT, level $4 \mathrm{~g} / \mathrm{kg}$ pakan dan 6 $\mathrm{g} / \mathrm{kg}$ pakan tidak berbeda nyata. Oleh karena itu dapat disimpulkan bahwa suplementasi $S$. platensis $4 \mathrm{~g} / \mathrm{kg}$ pakan merupakan level yang paling efektif dalam menstimulasi produksi limfosit ikan gurami dan merupakan level terbaik untuk suplementasi.

Spirulina mengandung polisakarida sebesar 1,5\% bobot keringnya (Jawetz, 1982). Menurut Rustikawati (2012), polisakarida dapat meningkatkan sel imun yaitu dengan menginduksi sel pembentuk leukosit, untuk menghasilkan lebih banyak sel-sel yang terdapat dalam leukosit salah satunya yaitu limfosit.

Hasil sel monosit berdasarkan uji ANOVA yang dilakukan menunjukkan bahwa pemberian $S$. platensis dengan level pemberian $2 \mathrm{~g} / \mathrm{kg}$ pakan; $4 \mathrm{~g} / \mathrm{kg}$ pakan; dan $6 \mathrm{~g} / \mathrm{kg}$ pakan tidak memberikan pengaruh yang nyata $(\mathrm{P}>0,05)$ dihari ke-14 dan berpengaruh nyata dihari ke-28 hingga hari ke-56. Namun persentase monosit yang didapatkan dari semua perlakuan cenderung dibawah persentase monosit pada kontrol (Gambar 6). Hasil penelitian ini tidak sesuai dengan hasil penelitian yang dilaporkan oleh Sahan et al., (2015) bahwa suplementasi S. platensis meningkatkan persentase monosit ikan nila. Penurunan monosit diduga karena monosit meninggalkan pembuluh darah karena waktu paruh dan masa hidup monosit yang pendek, seperti yang dinyatakan oleh Guyton \& Hall (1997), bahwa masa hidup monosit sangat cepat hanya berkisar 10 - 20 jam setelah diproduksi.

Sementara hasil sel neutrofil berdasarkan uji ANOVA yang dilakukan menunjukkan bahwa pemberian S. platensis dengan level pemberian $2 \mathrm{~g} / \mathrm{kg}$ pakan; $4 \mathrm{~g} / \mathrm{kg}$ pakan; dan $6 \mathrm{~g} / \mathrm{kg}$ pakan tidak memberikan pengaruh yang nyata $(\mathrm{P}>0,05)$ dihari ke-14 dan berpengaruh nyata dihari ke-28 hingga hari ke-56. Namun persentase neutrofil yang didapatkan dari semua perlakuan cenderung dibawah persentase neutrofil pada kontrol (Gambar 7). 
Fluktuasi dan rendahnya persentase neutrofil yang didapatkan dalam penelitian ini diduga karena waktu paruh neutrofil beredar yang pendek, seperti yang dinyatakan oleh Fischer et al. (1998), bahwa waktu paruh sel granulosit beredar dalam darah hanya sekitar tiga hari. Setiawan et al. (2012) menyatakan bahwa sebagaimana halnya monosit, neutrofil juga merupakan sel berumur pendek sehingga jumlahnya dalam darah berfluktuasi.

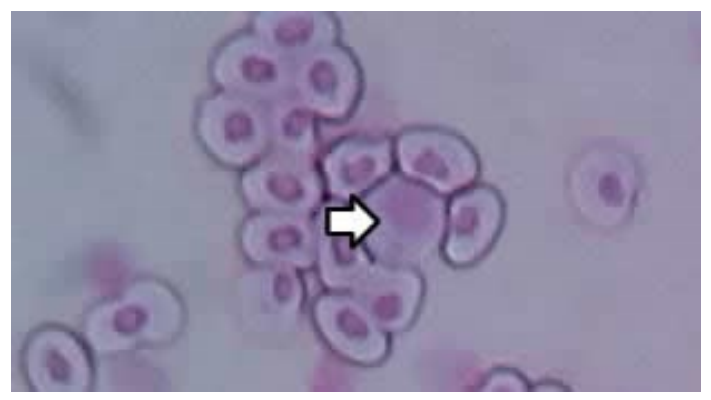

Gambar 1. Sel Limfosit Ikan Gurami (Perbesaran 400x)

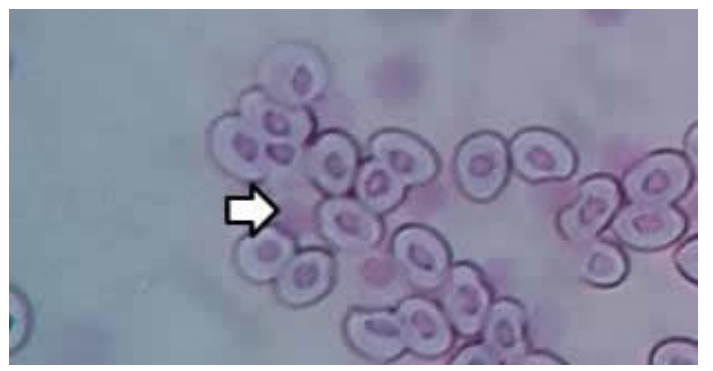

Gambar 2. Sel Monosit Ikan Gurami (Perbesaran 400x)

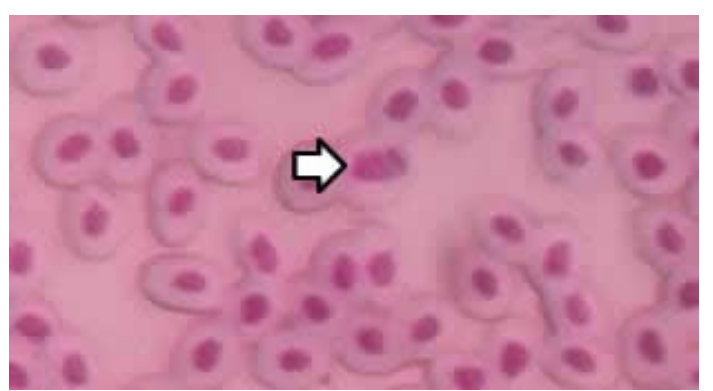

Gambar 3. Sel Neutrofil Ikan Gurami (Perbesaran 400x)

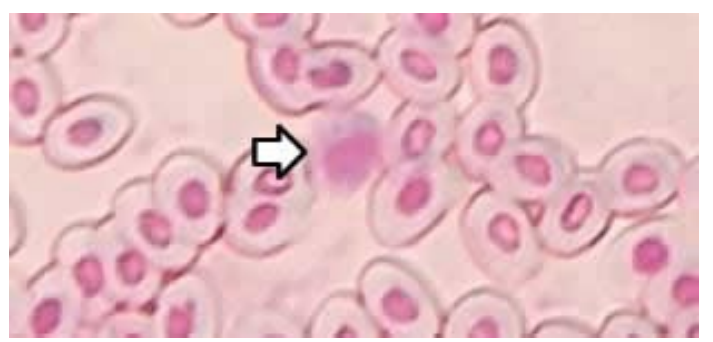

Gambar 4. Sel Eosinofil Ikan Gurami (Perbesaran 400x)

Berdasarkan uji ANOVA diketahui bahwa pemberian S. platensis dengan level pemberian $2 \mathrm{~g} / \mathrm{kg}$ pakan; $4 \mathrm{~g} / \mathrm{kg}$ pakan; dan $6 \mathrm{~g} / \mathrm{kg}$ pakan hanya memberikan pengaruh nyata $(\mathrm{P}<0,05)$ terhadap persentase eosinofil ikan gurami pada hari ke-42. Namun persentase eosinofil yang didapatkan dari semua perlakuan cenderung dibawah persentase eosinofil pada kontrol (Gambar 8).

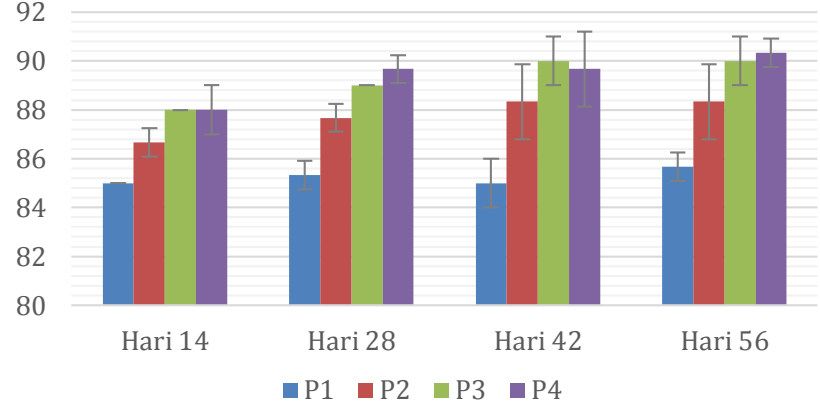

Gambar 5. Rerata persentase limfosit tiap perlakuan pada tiap pengamatan. (P1) pemberian pakan tanpa S. platensis; dan pemberian pakan dengan suplementasi S. platensis (P2)

$2 \mathrm{~g} / \mathrm{kg}$ pakan, (P3) $4 \mathrm{~g} / \mathrm{kg}$ pakan, (P4) $6 \mathrm{~g} / \mathrm{kg}$ pakan.

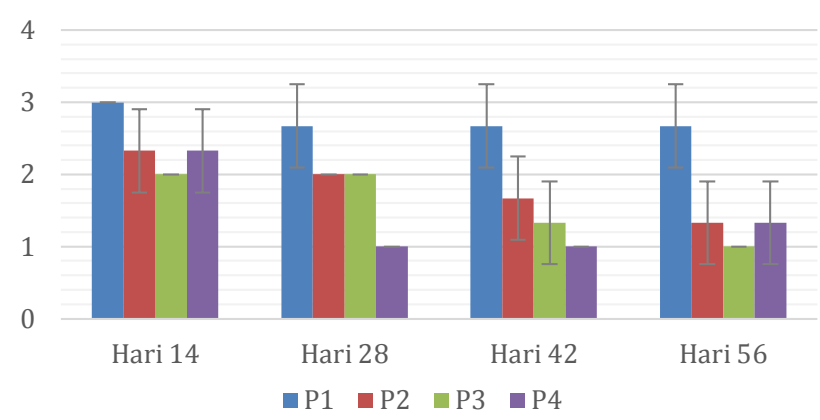

Gambar 6. Rerata persentase monosit tiap perlakuan pada tiap pengamatan. (P1) pemberian pakan tanpa S. platensis; dan pemberian pakan dengan suplementasi S. platensis (P2)

$2 \mathrm{~g} / \mathrm{kg}$ pakan, (P3) $4 \mathrm{~g} / \mathrm{kg}$ pakan, (P4) $6 \mathrm{~g} / \mathrm{kg}$ pakan.

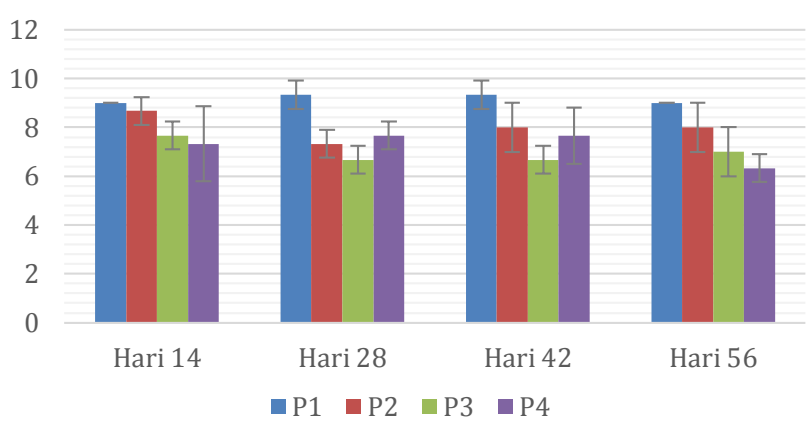

Gambar 7. Rerata persentase neutrofil tiap perlakuan pada tiap pengamatan. (P1) pemberian pakan tanpa S. platensis; dan pemberian pakan dengan suplementasi S. platensis (P2)

$2 \mathrm{~g} / \mathrm{kg}$ pakan, (P3) $4 \mathrm{~g} / \mathrm{kg}$ pakan, (P4) $6 \mathrm{~g} / \mathrm{kg}$ pakan.

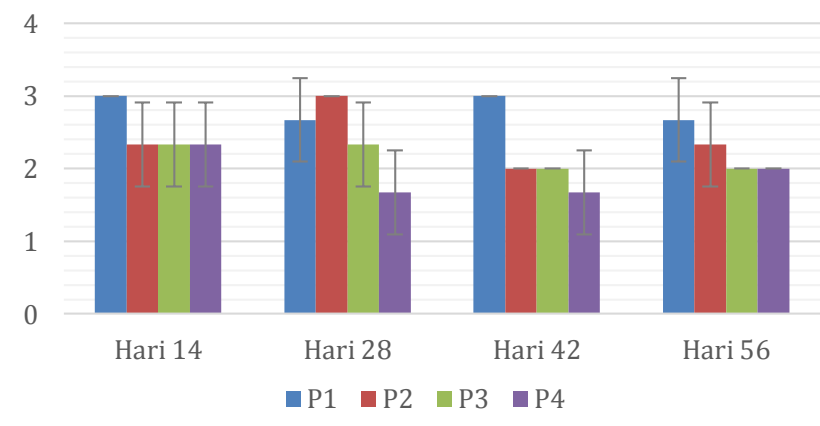

Gambar 8. Rerata persentase eosinofil tiap perlakuan pada tiap pengamatan. (P1) pemberian pakan tanpa S. platensis; dan pemberian pakan dengan suplementasi S. platensis (P2)

$2 \mathrm{~g} / \mathrm{kg}$ pakan, (P3) $4 \mathrm{~g} / \mathrm{kg}$ pakan, (P4) $6 \mathrm{~g} / \mathrm{kg}$ pakan. 
Persentase eosinofil yang berfluktuasi dan cenderung dibawah kontrol disebabkan karena waktu edar eosinofil yang singkat, seperti yang dinyatakan oleh Ramnik (2003), bahwa waktu pembentukan eosinofil diperkirakan 2-6 hari, kemudian eosinofil yang terbentuk terkativasi dan dapat meningkatkan pertahanan tubuh ikan. Usia eosinofil dalam sirkulasi yaitu 6-12 jam, dan kemudian akan bertahan hidup dalam jaringan selama dua minggu.

Hasil yang didapat dari keempat parameter yaitu limfosit, monosit, neutrofil dan eosinofil menunjukkan suplementasi S. platensis $4 \mathrm{~g} / \mathrm{kg}$ merupakan level yang efisien dan efektif untuk meningkatkan sistem imun ikan gurami terutama sel limfosit.

\section{KESIMPULAN DAN SARAN}

Berdasarkan hasil yang didapat, maka dapat disimpulkan; diferensial leukosit ikan gurami, Osphronemus gouramy, mengalami peningkatan setelah diberi suplementasi Spirulina platensis terutama terhadap persentase limfosit dan level suplementasi $S$. platensis $4 \mathrm{~g} / \mathrm{kg}$ pakan merupakan level suplementasi yang efektif menstimulasi diferensial leukosit ikan gurami.

Berdasarkan penelitian ini dapat disarankan bahwa dalam proses budidaya, ikan gurami dapat diberi suplementasi Spirulina platensis dengan level 4 $\mathrm{g} / \mathrm{kg}$ pakan untuk meningkatkan kekebalan tubuh ikan.

\section{DAFT AR REFERENSI}

Abdel-Tawwab M, Ahmad HM. 2009. Live Spirulina platensis (Arthrospira platensis) as a growth and immunity promoter for Nile tilapia, Oreochromis niloticus (L.), challenged with pathogenic Aeromonas hydrophila. Aquaculture Res. 40:10371046.

Bachtiar Y. 2010. Budidaya dan Bisnis Gurami. Jakarta: PT Agromedia Pustaka.
Fischer U, Ototake M, Nakanishi T. 1998. Life span of circulating blood cells in ginbuna crucian carp (Carassius auratus langsdorfii). Fish \& Shellfish Immunology. 8(5):339-349.

Guyton AC, Hall JE. 1997. Buku Ajar Fisiologi Kedokteran Edisi 9. Penerbit Buku Kedokteran EGC.

Handari SS. 1983. Metode Pewarnaan. Jakarata: Bhatara Karya Aksara.

Jawetz. 1982. Mikrobiologi untuk profesi kesehatan. Edisi Keempat belas. Jakarta: Buku kedokteran.

Nur MMA. 2014. Potensi Mikroalga sebagai Sumber Pangan Fungsional di Indonesia. Eksergi. 11(2):1-6.

Purwanto A. 2006. Gambaran Darah Ikan Mas (Osphronemus gouramy) yang Terinfeksi Koi Herpes Virus. [Skripsi]. Bogor: Program Studi Teknologi dan Manajemen Akuakultur. Fakultas Perikanan dan Ilmu Kelautan. Institut Pertanian Bogor.

Ramnik S. 2003. Haematology for students and practitioners. 5th edition. New Delhi: Jaypee Brothers.

Rukmana HR. 2005. Ikan Gurami (Pembenihan dan Pembesaran). Yogyakarta: Kanisius.

Rustikawati I. 2012. Efektivitas Ekstrak Sargassum sp. Terhadap Diferensial Leukosit Ikan Nila (Oreochromis niloticus) Yang Diinfeksi Streptococcus iniae. Jurnal Akuatika. 3(2):125-134.

Sahan A, Taşbozan O, Aydin F, Özütok S, Erbaş CDS, Uslu L, Özcan F. 2015. Determination of Some Haematological And Nonspecific Immune Parameters in Nile Tilapia (Oreochromis Niloticus L., 1758) Fed with Spirulina (Spirulina Platensis) Added Diets. Journal of Aquaculture Engineering and Fisheries Research. 1(3):133-139.

Septiarini, Harpeni E, Wardiyanto. 2012. Pengaruh Waktu Pemberian Probiotik Yang Berbeda Terhadap Respon Imun Non-Spesifik Ikan Gurami (Osphronemus gouramy L.) Yang Diuji Tantang Dengan Bakteri Aeromonas salmonicida. Jurnal Rekayasa dan Teknologi Budidaya Perairan. 1(1):1-8.

Setiawan RB, Iriana D, Rosidah. 2012. Efektivitas Vaksin dari Bakteri (Mycobacterium fortuitum) yang Diinaktivasi dengan Pemanasan untuk Pencegahan Penyakit Mycobacterium pada Ikan Gurami (Osphronemus gouramy). Jurnal Perikanan dan Kelautan. 3(1):25-40.

Svobodova Z, Vykusova B. 1991. Diagnostics, prevention and therapy of fish diseases and intoxications. Czechoslavakia: Research Institute of Fish Culture and Hydrobiology Vodnany.

Utomo NBP, Rahmatia F, Setiawati M. 2012. Penggunaan Spirulina platensis sebagai suplemen bahan baku pakan ikan nila Oreochromis niloticus. Jurnal Akuakultur Indonesia. 11(1):4953. 